\title{
The Role of Quality of Work Life in Organizational Commitment in Islamic Banks
}

\author{
Mahmoud Ali Alrousan ${ }^{1} \&$ Shireen Mahmoud AlAli ${ }^{1}$ \\ ${ }^{1}$ Ajloun National University, Jordan \\ Correspondence: Shireen Mahmoud AlAli, Ajloun National University, Jordan.
}

Received: January 15, 2020

Accepted: March 19, 2020

Online Published: July 12, 2020

doi:10.5430/ijfr.v11n4p515

URL: https://doi.org/10.5430/ijfr.v11n4p515

\begin{abstract}
The study aims to identify the correlation and impact relationship between the quality of work life and the organizational commitment, and to show the strength of this relationship and its impact, and then provide a theoretical framework for the study variables. The practical aspect was distributed over a sample consisting of (77) persons working in Islamic banks. After the collection and processing of data using the statistical program (spss), the results showed a positive relationship between the variables of the study as well as the existence of a positive effect and accordingly, a number of recommendations were made.
\end{abstract}

Keywords: quality of work life, organizational commitment

\section{Introduction}

Today, business organizations are living in unstable environments that lead them to adapt to these changes. The human element and the creation of a work environment with certain characteristics are the main factor on which the success and development of the organization depend in order to increase creativity, loyalty and belonging. Accordingly, the current study aims to test the correlation between the quality of working life and organizational commitment. The study was conducted on the Jordanian Islamic banks.

\subsection{Study Problem}

The human element is one of the most important resources in the organizations and the main engine for their success. With the great changes in the working conditions and the size of the challenges faced by the organizations, the commitment of the workers is one of the things that should be concerned by the management of these organizations if there is a requirement for a good working life, which reflects on their loyalty and commitment, and this is sought by the Islamic banks of Jordan, so the study will try to answer the following questions:

1. What is the degree of interest of Islamic banks in the quality of work life?

2. What is the level of the organizational commitment of employees of Jordanian Islamic banks?

3. Is there a relationship between the quality of working life and the organizational commitment of the employees of the Jordanian Islamic banks?

\subsection{Importance of the Study}

The study draws its importance through researching in two variables at a great rate at present, as the volume of competition among the organizations requires it to secure the best working environment for the employees to achieve a high degree of satisfaction and loyalty and desired success. As the Jordanian Islamic banks over the past years have achieved a great success and has an important role in the national economy, this study came to highlight these variables according to the limits of the researchers' knowledge.

\subsection{Objectives of the Study}

The study aims to achieve the following objectives:

1. To know the degree of interest in the quality of working life at the Jordanian Islamic banks.

2. Identifying the level of organizational commitment.

3. Studying the relationship between the quality of working life and organizational commitment. 
4. Studying the impact of quality of work on the organizational commitment.

5. Presenting a number of activities for the relevant committees.

\subsection{Previous Studies}

- (Al-Omari and Al-Yafi, 2017), the objective of this study was to investigate the impact of the quality of the work factors affecting the civil servants. The study was conducted in Saudi Arabia and showed that the most important elements of quality of life affect social relations, job satisfaction, material incentives and performance evaluation.

- (Ibrahim, 2017) examined the role of mediation of self empowerment in strengthening the relationship between the impact of the behavior of organizational citizenship in the organizational commitment and conducted a study on private hospitals in Baghdad, and it turned out that the behavior of organizational citizenship and organizational commitment are crucial factors in the organizational performance.

- (Saleh, 2016) aimed at diagnosing the relationship between the dimensions of psychological capital and the organizational commitment. The study was conducted on the employees of the General Company for Fertilizer Industry in Basra Governorate.

- (Saghi et al., 2015) examined the intermediate role of the quality of work between organizational justice and organizational citizenship behavior at Azad University in Iran, and it found that the quality of the work does not enhance the relationship between the variables.

- (Hunker, 2014) examined the factors that can contribute positively to improving the quality of the work of non-permanent workers and show that there are many factors, including credibility, pride of the worker, friendship, respect, justice, job security, wages and opportunities for growth and advancement.

- (Bahr and Nasar, 2014) examined the impact of quality of work life on the development of employment as one of the aspects of interaction and belonging by employees towards their organizations and the study was conducted by the Department of Education. It was found that the level of quality of life is higher among the employees of the Department of Education at UNRWA.

\subsection{Study Hypotheses}

The first hypothesis: There is a significant correlation between the quality of work life and organizational commitment with its indicators.

The second hypothesis: There is a statistically significant relationship of the quality of work life in the organizational commitment illustrated by its indicators.

\section{Method}

\subsection{Community and Sample Study}

Employees of Jordanian Islamic Banks (Jordan Islamic Bank (2.236) Employees, Arab Islamic Bank (877 Employees), the questionnaire was randomly distributed to sample as shown in Table 1.

Table 1. Distribution of the study sample according to the banks

\begin{tabular}{|c|c|c|c|c|}
\hline Bank & $\begin{array}{ll}\text { Number } & \text { of } \\
\text { distributed } & \\
\text { questionnaires } & \end{array}$ & $\begin{array}{l}\text { Number of retrieved } \\
\text { questionnaires }\end{array}$ & $\begin{array}{l}\text { Number } \\
\text { excluded } \\
\text { questionnaires }\end{array}$ & $\begin{array}{l}\text { Number of valid } \\
\text { questionnaires for } \\
\text { analysis }\end{array}$ \\
\hline Jordan Islamic bank & 500 & 424 & 18 & 406 \\
\hline Arab Islamic Bank & 200 & 178 & 7 & 171 \\
\hline Total & 700 & 602 & 25 & 577 \\
\hline
\end{tabular}

- Jordan Islamic Bank: The Jordan Islamic Bank was established as a public joint stock company on 28 November 1978 under the provisions of the Companies Law No. 12 of 1964 and its main headquarters in Amman.

- Arab Islamic International Bank: started its banking operations in accordance with the provisions of the Islamic Shariah on February 9, 1998, and today it is one of the most prominent Islamic banking institutions in Jordan. 
The Islamic Bank of Jordan and the Arab Islamic International Bank provide all financial, banking and investment activities organized on a non-usury basis in accordance with the provisions of the Islamic Sharia through their positions and branches across the Kingdom.

\subsection{Data Collection Methods}

The two researchers went to obtain the data through the first two books related to cover the theoretical side and the second is the questionnaires, which were prepared specifically for field data.

\subsection{Statistical Methods}

A number of statistical methods were used, with the help of statistical program (spss v20), namely: arithmetic mean, standard deviation, coefficient of variation, Pearson correlation coefficient, $t, f$ tests and Interpretation $R^{2}$

\subsection{Measuring the Credibility and Stability of the Questionnaire}

1. The credibility of the questionnaire was done by following the veracity of the truth by presenting it to a number of experts and arbitrators in the field of jurisdiction to indicate the credibility of the items for the purpose of the study. Then, deleting, adding and merging some items to become (31) divided into two main variables including (16) item for the variable of quality of work life and (15) for the variable of organizational commitment using Likert scale (not strongly agreed, not agreed, neutral, agreed, strongly agreed) with the weights $(1,2,3,4,5)$, respectively, and the percentage of the opinion agreement was $(75 \%)$ influenced by each practice to indicate its validity.

2. Determination in order to determine the accuracy of the responses of the individuals in the study sample, the midterm split method was used as one of the most widely used methods and to find the correlation coefficient through Guttman formula, which is the most valid and common stability coefficient. The result of the coefficient was (0.83), which was positive and strong, indicating the stability of measuring the scale.

\subsection{Theoretical Framework}

\section{- First: quality of work life}

Concept and dimensions: Despite the emergence of the concept of quality of work life in the seventies of the last century, the attention is still increasing with the concern of workers in raising the level of education and professional ambition at a time when the world economies decline in economic growth and opportunities for progress and development, which increased the attention to quality of work life and personal life planning (Bharathi et al., 2011,48). The book presented many views on the concept of quality of working life, which was considered by Yadav and Khanna $(2014,71)$ to reflect the basic requirements aimed at improving the satisfaction of workers enhancing organizational effectiveness, and maximum extent to which employees can access their personal needs at work (Geet and Deshpanda, 2009,212). Moreover, (Albabisi, 2012, 7) stated it is the policies, procedures and processes implemented by the organization in order to develop and improve the personal and professional life of its employees, which reflects on the performance of the organization and individuals positively. (Chetoy, 2014, 21) defined it as a state of satisfaction of workers towards the material and moral work environment.

Consistent with the above, it can be said that the quality of working life is not something random, but a deliberate intentional act that works to strike a balance between the professional and family life of the workers, so that there is a harmony between social justice and the dignity of employees with the highest values of the organization by providing suitable and secure working conditions to raise the level of workers and provide an environment conducive to the development of the organization.

As for the dimensions of the quality of working life, (Ahmadi, 2012,246) identified it as job security, the best system of remuneration and fair and high wages and opportunities for promotion and work advancement (Jad Alrub, 2008,5) identified the dimensions with a healthy and safe working environment, design and enriching jobs, equity in wages and incentives, work advancement opportunities, balance and harmony between the work and personal lives of employees.

Marta et al (2011) presented a vision for the dimensions of quality of work life as consisting of health and safety needs, economic and family needs, social needs, recognition and appreciation needs, cognitive needs, knowledge needs, and aesthetic needs. (Munidi, 2015,225) considered it as containing material benefits as well as administrative behavior towards employees.

(UKKO, 2009,413) adopts the dimensions of the quality of work by stimulating work, imposing learning, growth, job satisfaction, work environment, health and safety, participation in decision making, achieving personal goals, team work and reward systems. 
Based on the above, we find that there is a variance and multiple interpretations of the dimensions of the quality of work life, but the researchers will adopt the following variables (characteristics of the job, the equivalence of wages, bonuses, participation in decision-making, moral work conditions), the most dimensions that have been adopted in previous studies, which goes with the field of the study.

\section{- $\quad$ Second: Organizational Commitment}

The organizational commitment has been very important in the management of human resources and the literature of psychology and has been considered a central characteristic of high performance workplaces (Brawn et al., 2011, 2). The researchers have worked hard to define the concept of organizational commitment, (Parra and Castillo, 2013,1073 ) refers to the organizational obligation of being within the framework of reciprocity theory, which means that a person who receives a good treatment by a person or an organization, will feel the mutual commitment, which will be reflected positively on the organization. (Anis et al., 2011,7319) defined it as the psychological stability or useful force that links individuals to the organization's work processes. (Markos and Sridevi, 2010, 90) noted that commitment is an indicator of the individual's willingness to be positive and willing to make an effort for the success of the organization, and the sense of pride of being an individual in this organization.

It can be said that there are two main inputs to the study of commitment in the organization: first, attitudes related to commitment and the other behaviors related to commitment. Three trends can be identified in defining the concept of the first commitment: the tendency of the individual towards the organization and the association with it; the second is the individual's desire to remain and connect with the organization by linking the interests of the individual to the interests of the organization and the third result of a multiple force that represents a group of psychological factors with a reciprocal structural nature. (Altal, 2010, 78) described the organizational commitment as the desire of the individual to identify with the organization and unwilling to leave it and the desire to work with and contribute to the effectiveness of the organization and willingness to make personal sacrifices and performance exceeding the normal expectations and acceptance of the values of the organization and its objectives (Ugboro, 2006), 236).

The importance of organizational commitment highlights because of its association with a number of behavioral phenomena related to the direction and behavior of the individual, whether its organization or the community's. It is as any other behavioral variable which does not represent a tangible reality, but it is inferred through the phenomena or effects resulting from the availability of the individual or not, and cannot be obtained directly, it is the result of many interactions and many factors and variables (Fahdawi and Qatouna, 2004,12) .

The importance of the organizational commitment can be demonstrated as one of the indicators of predicting the organization's role as well as being an important factor in predicting the effectiveness of the organization. In addition, the organizational commitment is important in the circumstances of the crises that can pass through it.

As for the dimensions of the organizational commitment, we find that there are three dimensions collected by the studies that dealt with this subject, represented by:

First: Emotional commitment refers to commitment, emotional attachment, conformity or integration with the values and objectives of the organization (Felt, 2003,2). The emotional commitment is the emotional perception and participation of individuals and others, which comes from the experience of work (Kuo, 2013,42) In the distribution of rewards and clarity of role, freedom from conflict and participation in decision-making plays a large role in the individual's sense of commitment to the organization (Humphreys, et al., 2005,120), while (Newman and Sheikh, 2012,73) described the emotional commitment according to the theory of social exchange or the so-called (psychological contract) between the employer and the employee.

Second: the normative commitment reflects the role of the individual and the commitment to his continuing work within the organization. (Salami, 2008,32) described the normative obligation as a sense of duty dominates the individual (Parra and Castillo, 2013,1073) (Girdington, 2009,217) referred to the concept of normative commitment as an individual's sense of commitment to stay in the organization because of the pressures of others, as they do not want to cause concern to the organization or to leave a bad impression on colleagues.

Third: the continuous commitment is one of the forms of psychological engagement with the organization, which reflects employees' perception of the loss they may incur when leaving the organization. (Kazlauskaite et al., 2006, 303) said that the costs resulting from the abandonment of an individual's membership in the organization can be (Such as retirement) or social (such as relationships with individuals). Here the obligation is not voluntary, but the individual feels obliged to avoid unpleasant consequences (Vell et al., 2013, 352). 


\section{Analysis of Results and Hypothesis Testing}

\subsection{Descriptive Analysis of Study Data}

Table 2 shows the order of relative importance from the point of view of the sample in banks to indicators of the quality of work life according to the difference coefficient. The fairness of wages and financial rewards ranked in the first place, the participation index in decision-making ranked in the second place, the characteristics of the job ranked in the third place, and the conditions of moral work ranked in the fourth place.

Based on the above, the management of banks should give priority to the indicators that obtained the least degree of importance from the answers in order to pay attention to them and identify ways to contribute to the quality of work life.

Table 2. To determine the relative importance of labor quality indicators

\begin{tabular}{|c|c|c|c|c|}
\hline Indicators & Arithmetic mean & Standard deviation & Coefficient of variation & Relative order \\
\hline Functional properties & 3.34 & 0.92 & 27.54 & $3^{\text {rd }}$ \\
\hline $\begin{array}{l}\text { equity of wages and } \\
\text { rewards }\end{array}$ & 3.47 & 1.09 & 19.82 & $1^{\mathrm{st}}$ \\
\hline $\begin{array}{l}\text { Participation } \\
\text { decision-making }\end{array}$ & 3.30 & 1.06 & 24.86 & $2^{\text {nd }}$ \\
\hline $\begin{array}{l}\text { Moral working } \\
\text { conditions }\end{array}$ & 3.48 & 0.69 & 31.41 & $4^{\text {th }}$ \\
\hline
\end{tabular}

Table 3 shows the order of relative importance from the point of view of the study sample to remove the indicators of the organizational commitment according to the coefficient of difference. The index of emotional commitment ranked in the first place and the normative commitment came in second place and the constant commitment in third place.

The decision maker must arrange decisions in the light of this and give priority to the indicators that have received the least attention to improve and develop them.

Table 3. Ranking the relative importance of organizational commitment indicators

\begin{tabular}{lllll}
\hline Indicators & Arithmetic mean & Standard deviation & Coefficient of variation & Relative order \\
\hline $\begin{array}{l}\text { Normative } \\
\text { commitment }\end{array}$ & 3.62 & 0.0719 & $1.98 \%$ & $2^{\text {nd }}$ \\
\hline $\begin{array}{l}\text { Emotional } \\
\text { commitment }\end{array}$ & 3.46 & 0.0605 & $1.75 \%$ & $1^{\text {st }}$ \\
\hline $\begin{array}{l}\text { Continued } \\
\text { commitment }\end{array}$ & 3.7 & 0.1155 & $3.12 \%$ & $3^{\text {rd }}$ \\
\hline
\end{tabular}

\subsection{Testing Hypotheses}

\subsubsection{Test the First Hypothesis}

It is clear from the results in Table 4 that there is a strong statistically significant correlation between the two main variables at the significant level (1\%). The correlation coefficient between them is 0.889 . (8.181) is greater than the tabular value of (1.69) which means that increasing the interest of the study sample in the quality of the work variable will contribute significantly to achieving the organizational commitment in the bank. What can be seen in the table above is also a strong positive relationship between the variable organizational commitment and each dimension of the quality of working life at the significant level (1\%), with the confidence level (99\%). What supports this is that the value of $(\mathrm{T})$ calculated for each dimension reached $3.36(3,928,4,133,3,517)$, respectively, which is larger than the tabular value of (1.69), which indicates the acceptance of the hypothesis that there is a statistically significant correlation between the quality of work life and the organizational commitment with its indicators. 
Table 4. The coefficient correlation between the two variables

\begin{tabular}{|c|c|c|c|c|c|c|}
\hline \multirow{2}{*}{$\begin{array}{l}\text { Independent } \\
\text { vepariable } \\
\text { variable }\end{array}$} & \multirow{2}{*}{$\begin{array}{l}\text { Quality of } \\
\text { working } \\
\text { life }\end{array}$} & \multicolumn{4}{|c|}{ Quality of work life dimensions } & \multirow{2}{*}{$\begin{array}{l}\text { Value of } \\
\text { T-table }\end{array}$} \\
\hline & & $\begin{array}{l}\text { Work } \\
\text { characteristics }\end{array}$ & $\begin{array}{l}\text { Equity of } \\
\text { wages and } \\
\text { rewards }\end{array}$ & $\begin{array}{l}\text { Participation in } \\
\text { decision-making }\end{array}$ & $\begin{array}{l}\text { Moral } \\
\text { working } \\
\text { conditions }\end{array}$ & \\
\hline $\begin{array}{l}\text { Organizational } \\
\text { commitment }\end{array}$ & 0.889 & 0.66 & 0.76 & 0.78 & 0.67 & 1.69 \\
\hline $\begin{array}{l}\text { Calculated value of } \\
\text { (T) }\end{array}$ & 4.636 & 3.361 & 3.928 & 4.133 & 3.517 & $\begin{array}{l}99 \% \\
\text { confidence }\end{array}$ \\
\hline
\end{tabular}

\subsubsection{Test the Second Hypothesis}

For the purpose of measuring the relationship between the two main variables, the researchers used the $\mathrm{F}$ test. The interpretation coefficient $\left(\mathrm{R}^{2}\right)$ was used to measure the percentage of the quality of work life from changes in the organizational commitment in the study sample. After the statistical analysis, by noting the results in Table 5:

A. The quality of working life has a strong effect on the organizational commitment. This is the effect of the calculated value of $(\mathrm{F})$, which means that there is an effect relationship between the two variables with statistical significance at a significant level $(1 \%)$.

B. The ratio of the quality of working life to the impact of organizational commitment $\left(\mathrm{R}^{2}\right)$ was $(81 \%)$, while the remaining $19 \%$ is due to the contribution of other variables.

C. The value of calculated (F) for the quality of working life was 11,296, 15,429, 17,081, and 12.369 respectively, which is larger than the tabular value of (3.7). This means that there is a significant statistical relationship at a significant level (1\%) among the dimensions of quality of work life and organizational commitment.

As shown by the value of the interpretation factor $\left(\mathrm{R}^{2}\right)$ of $(0.408,0.561,0.622$, and 0.447$)$, the ratio of the explanatory dimension of the changes in the organizational commitment was $40.8 \%, 56.1 \%, 62.2 \%$ and $44.7 \%$ respectively. The remaining $59.2 \%, 43.9 \%, 37.8 \%$ and $55.3 \%$ are contributing to other variables.

Based on the above, the second hypothesis that a statistical significance relationship between the quality of work life and the organizational commitment with its indicators can be accepted.

Table 5. Relationship between the quality of work life and organizational commitment

\begin{tabular}{|c|c|c|c|c|c|c|}
\hline \multirow{2}{*}{$\begin{array}{l}\text { Independent } \\
\text { vepariable } \\
\text { Variable }\end{array}$} & \multirow{2}{*}{$\begin{array}{l}\text { Quality } \\
\text { of } \\
\text { working } \\
\text { life }\end{array}$} & \multicolumn{4}{|c|}{ Quality of working life dimensions } & \multirow{2}{*}{$\begin{array}{l}\text { Tabular } \\
\text { value }(\mathrm{F})\end{array}$} \\
\hline & & $\begin{array}{l}\text { Work } \\
\text { characteristics }\end{array}$ & $\begin{array}{l}\text { Equity of } \\
\text { wages and } \\
\text { rewards }\end{array}$ & $\begin{array}{l}\text { Participation in } \\
\text { decision-making }\end{array}$ & $\begin{array}{l}\text { Moral work } \\
\text { conditions }\end{array}$ & \\
\hline $\begin{array}{l}\text { organizational } \\
\text { commitment }\end{array}$ & 0.90 & 0.639 & 0.749 & 0.789 & 0.669 & 3.7 \\
\hline $\begin{array}{l}\text { Calculated }(\mathrm{F}) \\
\text { value }\end{array}$ & 21.492 & 11.296 & 15.429 & 17.081 & 12.369 & $\begin{array}{l}\text { Confidence } \\
\text { degree } 99 \%\end{array}$ \\
\hline $\begin{array}{l}\text { interpretation } \\
\text { coefficient }\left(\mathrm{R}^{2}\right)\end{array}$ & 0.81 & 0.408 & 0.561 & 0.622 & 0.447 & \\
\hline
\end{tabular}

\section{Conclusions}

1. It was found that the arithmetic mean of all indicators of quality of work life exceeded the satisfactory mean (3) which means that there is a good level of quality of work life.

2. The arithmetic mean of all indicators of organizational commitment has exceeded the satisfactory medium, which means that there is a good degree of organizational commitment. 
3. There is a statistically significant correlation between the quality of work life and organizational commitment with its indicators.

4. There is an impact relationship between quality of work life and organizational commitment.

5. Moral conditions are good compared to other indicators of quality of work.

6. Continuing commitment between indicators of organizational commitment.

\section{Recommendations}

1. Incomplete incentives and rewards in order to improve the quality of work life.

2. The involvement of decision makers and their industry has a positive role in improving the quality of work life.

3. Enhancing the sense of the bank's employees.

4. Familiarize the family atmosphere in the banking environment.

5. Emphasize that the objectives of the bank correspond to the social values of the Jordanian society.

6. The management provides employees with continuous support.

7. Provide an atmosphere of trust and respect among employees.

8. Spreading the democratic atmosphere among employees.

9. Effective use of staff knowledge and skills.

10. The Impact of Quality-Work life Dimensions on of Administrative Decisions Making.

\section{References}

Ahmadi, F., \& Salavati, M. (2012). A survey relationship between quality of work life and organizational commitment in public organization in Kurdistan province. Interdisciplinary Journal of Contemporary Research in Business, 4(1).

Al-Omari, M. B. S., \& Salameh, R. (2017). The Effect of the Quality of Work on the Performance of the Public Employee in the Kingdom of Saudi Arabia. Jordanian Journal of Business Administration, 3(1).

Anis, A., Rehman, I., Khan, M., \& Humayoun, A. (2011) impact of organizational commitment on job satisfaction and employee retention in pharmaceutical industry. African Journal of Business Management, 5(17). https://doi.org/10.5897/AJBM10.1296

Ashtewi, M. (2014). Attitudes Towards Quality of Life in Gaza Municipality. Unpublished PhD thesis, Al Quds Open University, Gaza.

Bahr, Y. A. A., \& Nassar, A. H. (2014). Quality of Work Life and its Impact on Work Development. Published by the Arab Organization for Administrative Development, Cairo, Egypt.

Bharathi, P., Kumar, N., \& Umaselvi, M. (2011). Quality of work life: Perception of college Teachers. Indian Journal of Commerce and Management Studies, 11(1).

Bilbisi, O. Z. (2010). The quality of work and its impact on the performance of the employees of non-governmental organizations in Gaza Strip. Unpublished master thesis, Islamic University of Gaza.

Brown, B., Mchardy, J., Mcnabb, R., \& Taylor, K. (2011). Workplace performance worker commitment and loyalty. Discussion paper series, IZADP No5447, formschungs institute, zurzukunft der arbeit, institute for the study of labor. https://doi.org/10.1111/j.1530-9134.2011.00306.x

Fahdawi, F., \& Khalifa, Q. (2004). The Effects of Organizational Justice on Organizational Loyalty - A Field Study of Central departments in the Southern Governorates of Jordan. The Arab Scientific Journal of Administration, 2(24).

Felt, L. (2003). Organizational commitment duting public sector downsizing. Memorial University.

Geet, S., Deshpande, A., \& Deshpande, A. (2009). Human resource management (1st ed.). Niraliprakashan.

Giring, G., \& Ruert, B. (2009). Behavioral Management in Organizations. Arabi Rifai Mohammad Rifai and Ismail Ali Bassiouni, Dar Al Marikh Publishing and Distribution, Riyadh, Saudi Arabia.

Hunker, I. (2014). Quality of work life in the hospitality industry - the contingent workers perspective. MA thesis, Copenhagen business school. 
Ibrahim, I. K. (2017, March). The Intermediate Role of Psychological Empowerment in Promoting Organizational Citizenship Behavior in Organizational Commitment. Journal of Economic and Administrative Sciences, 25.

JadAlrub, S. (2008). Quality of work life QWL in Modern Business Organizations. Egypt, Dar Al Fikr Al Arabi Publishing.

Kazlauskaite, R., Bu cinciuniene, I., \& Turauskas, L. (2006). Building employee commitment in the hospitality industry. Baltic Journal of Management, 1(3). https://doi.org/10.1108/17465260610690944

Kuo, Y. (2013). Organizational commitment in an intense completion environment. Industrial Management and Data Systems, 113(1). https://doi.org/10.1108/02635571311289656

Markos, S., \& Sridevi, M. S. (2010). Employee Engagement the key to improving performance. International Journal of Business and Management, 5(12). https://doi.org/10.5539/ijbm.v5n12p89

Marta, J. K., Msinghapakdi, A., Lee, D. J., Sirgy, M. J., Konmee, K., \&Virakul, B. (2011). perceptions about ethics institutionalization and quality of work lif: thai versus American marketing managers. Journal of Business Research.

Muindi, F. (2015). quality of work lifestyles, personality, job satisfaction, perception, and job performance a critical review of literature. European Scientific Journal, 11(26).

Newman, A., \& Sheikh, A. (2012). organizational rewards and employess commitment: achinese study. Journal of Managerial Psychology, 27(1). https://doi.org/10.1108/02683941211193866

Parra, A. O., \& Castillo, M. A. S. (2013). Impact of perceived corporate culture on organizational commitment. Management Decision, 51(5). https://doi.org/10.1108/MD-08-2012-0599

Saghi, S. K., Rezaefar, H., Zabihi, M. R., \& Mehdi. (2015). A survey of the mediation role of quality of work life in the impact of organizational justice on organizational citizenship behavior of administrative units in Azad. University Journal of Social Issues and Humanities, 3(5). https://doi.org/10.7763/JOEBM.2015.V3.296

Salami, S. O. (2008). Demographic and psychological factors predicting organizational commitment among industrial workers. Anthropologist, 10(1). https://doi.org/10.1080/09720073.2008.11891026

Saleh, R. M. (2016). The Impact of Psychological Capital in Achieving Organizational Commitment. Journal of Economic Sciences, 41(11).

Tal, A. Z. R. A. (2010). The Interrelationship between Some of the Fundamental Issues of Social Responsibility and Compensation for Quality and its Implications for Organized Values. Unpublished PhD thesis, Faculty of Management and Economics, University of Mosul.

Ugboro, I. (2006). Organizational commitment job redesign, employee empowerment and intent to quit among survivors of restructuring and downsizing. Institute of behavioral and applied management, all right reserved.

Ukko, J., et al.. (2009). The impact of performance measurement on the quality of work life. Int. J. Business Performance Management, 10(1). https://doi.org/10.1504/IJBPM.2008.015922

Yadav, R., \& Khanna, A. (2014). Literature review on quality of work life and their dimensions. IOSR Journal of Humanities and Science, 19(9). https://doi.org/10.9790/0837-19957180 